\title{
ОЦЕНКА ИНБРЕДНЫХ САМОНЕСОВМЕСТИМЫХ ЛИНИЙ РЕДЬКИ ЕВРОПЕЙСКОЙ ЛЕТНЕЙ
}

\section{(C) 2014 г. М.А. Косенко}

Дана оценка инбредной самонесовместимой линии редьки европейской летней. Проведены диаллельные скрещивания 8 самонесовместимых растений.

Ключевые слова: редька, защищенный грунт, самонесовместимость, сроки посева.

Inbred self-incompatibility lines assessment of summer European radish is submitted. Dialletic crossing of 8 self-incompatibility plants is carried out.

Key words: radish, sheltered ground, self-incompatibility, sowing duration.

Редька относится к ботаническому виду RaphanussativusL., семейству Капустные - BrassicaceaeBurnett. Корнеплоды, образующиеся в первый год, богаты минеральными солями, углеводами и витаминами и обладают бактерицидными свойствами.

В отечественном ассортименте наблюдается недостаток сортов летней редьки для возделывания в защищенном грунте.

Производство гибридных семян $\mathrm{F}_{1}$ имеет фундаментальное значение в современном овощеводстве как в отношении повышения урожайности и качества выращиваемой продукции, так и получаемой прибыли.

Многие местные сорта являются донорами ценных признаков. Редька летняя (сорт Одесская 5) обладает скороспелостью.

В зависимости от исходного материала и целей можно применять различные способы оценки растений. Для индустриальной технологии семеноводства нужна селекция семенных растений на дружность цветения и созревания семян, неосыпаемость и легкую обмолачиваемость плодов, высокую семенную продуктивность, выравненность по массе и энергии прорастания. Успех селекции зависит от знания закономерностей наследования признаков растений и сортовых популяций.

Опыты проводили в 2013 г. в отделе селекции ГНУ ВНИИО. По природномелиоративному районированию место исследований относится к южной лесной зоне европейской провинции в центральной ча- сти Русской равнины и входит во влажную зону.

Материалом исследований служили 18 самонесовместимых линий редьки европейской летней, отобранных и доведенных до 3-4 инбридинга из 3 коллекционных сортов отечественного и зарубежного происхождения,

Исследования проводили в питомнике исходного материала, расположенном на полях ОПХ «Быково» Раменского района Московской области, методами лабораторно-полевых опытов, сопровождающихся сопутствующими анализами.

В результате автогамных и гейтеногамных опылений из сортов редьки европейской летней были выделены самонесовместимые растения - родоначальники будущих линий.

Средняя длина корнеплода у инбредных линий 4-го поколения находилась в пределах 3,1..13,5 см. Индекс формы корнеплода изменялся от 0,71 до 3,86 . По форме корнеплоды линий распределились на: округлую - 33\%, плоскоокруглую - 28\%, округло-овальную - $22 \%$, цилиндрическую - 17\%. Коэффициент вариации длины корнеплода инбредных линий колебался от 0,3 до 17,8\%. Коэффициент вариации диаметра корнеплода инбредных линий находился в пределах от 0,4 до 20,2\%.

Самонесовместимые линии 4-го поколения проявили себя со слабой изменчивостью корнеплода № 21м(1)-2-1, № $21 \mathrm{M}(1)-5-9$, № $21 \mathrm{~m}(1)-8-4$, № $20 \mathrm{M}(3)-1-3$, № 15д(1)-2-1. 
Проведена оценка элементов урожая инбредных самонесовместимых линий $\mathrm{I}_{4}$ редьки европейской летней. Урожайность инбредных линий 4-го поколения варьировала от 1,27 до 2,96 кг/м².

Число товарных корнеплодов варьировало от 49,0 до $100,0 \%$. Наибольшее число было выявлено у линий № 15д(2)-5-8 $100 \%$, Суд $13-8$ - 100\%, № 21м(1)-5-9 $98,70 \%$, № 15д(2)-5-2 - 97,92\%. Процент недогонов колебался от 0,00 до $51,02 \%$. Больных корнеплодов не обнаружено. Число треснувших корнеплодов изменялось от 0,00 до $31,07 \%$.

Инбридинг, особенно длительный, наряду с положительными моментами, как, например, повышение коэффициента выравненности по признакам корнеплода, имеет и свои отрицательные стороны. Негативное влияние инбридинга характеризует степень инбредной депрессии. Степень инбредной депрессии по признаку средней массы корнеплода у инбредных линий $\mathrm{I}_{4}$, редьки европейской летней варьировала от 0,082 до $-0,379$.

В 2013 году нами был проведен второй срок посева гибридного материала и самонесовместимых линий. Посев производили по принятой схеме $20 \times 10$. Была изучена 21 гибридная комбинация (из 7 самонесовместимых линий) и 5 самонесовместимых линий скрещивания 2012 года.

Средняя длина корнеплода у инбредных линий находилась в пределах $3,1 \ldots$ 4,3 см. Средний диаметр корнеплода у инбредных линий был $3,2 \ldots 4,1$ см.

Индекс формы корнеплода у инбредных линий изменялся от 1,00 до 1,90. У гетерозисных гибридов F1 изменения составили от 0,91 до 3,20.

По форме корнеплоды линий распределились на округлую - 80,0\% и овальную $20,0 \%$. У гетерозисных гибридов F1 на цилиндрическую - 28,5\%, овальную - 9,5\%, округло-овальную - 23,8\% и округлую $38,2 \%$.

Коэффициент вариации длины корнеплода у инбредных линий колебался от 0,2 до 17,6\%. Коэффициент вариации диаметра корнеплода инбредных линий 4-го поколения изменялся от 8,6 до $15,4 \%$. Коэффици- ент вариации индекс формы изменялся от 12,1 до 25,1\%.

Коэффициент вариации длины корнеплода гетерозисных гибридов F1 колебался от 0,5 до 34,6\%. Коэффициент вариации диаметра корнеплода инбредных линий находился в пределах от 0,3 до 44,4\%. Коэффициент вариации индекс формы изменялся от 6,0 до $25,8 \%$.

Уровень товарности у инбредных линий 4-го поколения варьировал от 49,4 до $92,3 \%$. Процент недогонов изменялся от 7,7 до 39,2\%. Процент треснувших корнеплодов варьировал от 0,0 до 42,9\%.

Уровень товарности у гетерозисных гибридов F1 составлял от 61,8 до 100\%. Процент недогонов изменялся от 0,0 до $38,2 \%$.

Масса товарного корнеплода у инбредных линий 4-го поколения варьировала от 22,0 до 39,6 г. Урожайность корнеплодов

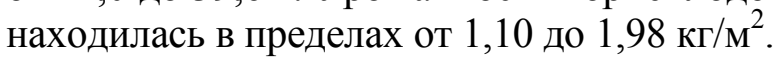

Масса товарного корнеплода у гетерозисных гибридов F1 изменялась от 15,0 до 56,6 г. Урожайность корнеплодов различалась от 0,75 до 2,83 кг/м².

Нами было определено проявление эффектов гетерозиса у гибридов первого поколения редьки европейской летней. В некоторых гибридных комбинациях происходило отрицательное проявление гетерозиса. Он варьировал от 100,0 до 157,3\%.

В результате проведения двух сроков посева было выявлено, что в 1 срок урожайность находилась в пределах от 1,42 до $2,96 \kappa г / \mathrm{m}^{2}$, а во 2 срок изменялась от 1,10 до $1,98 \mathrm{\kappa} / \mathrm{M}^{2}$.

Для раннего посева больше пригодна инбредная линия № 19м(3)-2-1, а для позднего посева инбредная линия № 15д(2)-1-2.

Для выявления проявления самонесовместимости в инбредных линиях 3-го поколения редьки европейской летней, нами были проведены автогамные опыления цветков и гейтеногамные опыления бутонов в пределах одного растения. В результате этих опылений были выявлены растения, завязавшие при автогамном опылении цветков семена. С данных растений семена не будут использованы в дальнейшей селекционной работе. Так же получили 
существенные изменения в проявлении признака самонесовместимости в положительную сторону в результате инбридинга. Расчёт производили на основе средних показателей завязываемости семян от опыления цветков и бутонов.

У инбредных линий 4-го поколения редьки европейской летней было определено, что величина среднего числа семян в стручке от опыления цветков колебалась от 0,00 до 0,83 шт., размах варьирования среднего числа семян в стручке от опыления бутонов изменялась от 2,37 до 3,60 шт.

Одна линия проявила себя как частично самонесовместимая $(32,5 \%)$. Все осталь- ные линии полностью самонесовместимые, уровень самонесовместимости находился в пределах 0,0 - 7,90\%.

В результате исследований было выявлено, что 11 самонесовместимых линий проявили себя как полностью самонесовместимые, в среднем уровень самонесовместимости не превышал 10\%. В 6-х линиях во всех растениях отсутствовало завязывание семян при автогамном опылении цветков, в 6 линиях такие растения были. В процессе инбридинга произошло увеличение количества самонесовместимых растений в линиях (рисунок 1).

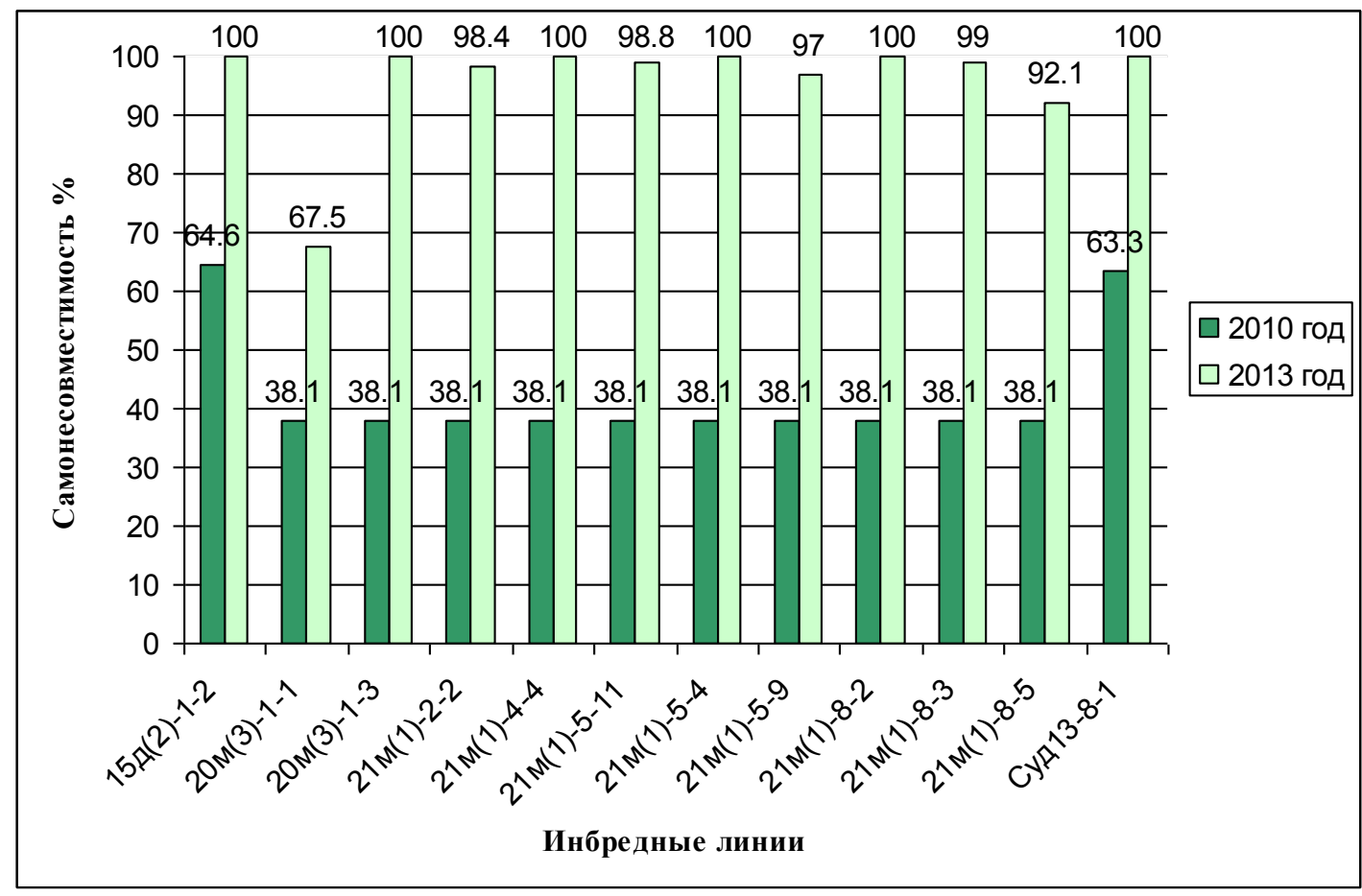

Рисунок 1 - Динамика проявления самонесовместимости в процессе инбридинга линий редьки европейской летней, 2010-2013 гг.

Нами так же были проведены диаллельные скрещивания 8 самонесовместимых растений. В результате оценки семенных растений редьки европейской летней, количество завязавшихся семян от родительских линий различалось от 1,0 (21 $(1)$ 4-4-1) до 4,3 (15д(2)-1-2-1) шт./стручок, гибридных семян изменялось от 1,0 до 6,3 шт./стручок.

Средняя завязываемость семян у всех родительских линий - 2,9 шт./стручок, у гибридов - 2,5 шт./стручок. В 2013 году была отмечена низкая завязываемость семян из-за продолжительных дождей.

Таким образом, анализ полученных результатов показывает, что уровень самонесовместимости инбредных линий

4-го поколения редьки европейской летней находился в пределах 0,0-32,5\%; у 6 линий отсутствовало завязывание семян после 
опыления в фазу цветка. Это говорит о том, что линия полностью самонесовместима.

В результате оценки семенных растений редьки европейской летней количество завязавшихся семян от родительских линий различалось от $1,0(21 \mathrm{M}(1)-4-4-1)$ до 4,3 (15д(2)-1-2-1) шт./стручок, гибридных семян изменялось от 1,0 до 6,3 шт./стручок.

Сведения об авторе

Косенко Мария Александровна - канд. с.-Х. наук, научный сотрудник ВНИИО, (д. Верея Раменского района Московской области). Тел.: 8-926-948-08-61.

\section{Information about the author}

Kosenko Maria Alexandrovna - Candidate of Agricultural Sciences, research associate of the Selection department, All-Russian Research Institute of Vegetable Growing (Ramensky district, Verey's village, Moscow region). Phone: 8-926-948-08-61. 